\title{
Evolution of research methodology on the role of higher education in socio-economic development
}

\author{
Elena Molokova* \\ Ural State University of Economics, 8 Marta str./Narodnaya Volya, 62/45, 620144 Yekaterinburg, \\ Russia
}

\begin{abstract}
The article analyses the development of research methodology on the role (contribution) of higher education. It is noted that the field of research on the meaning (contribution or role) of higher education is always determined by the historical context of its development. The relevance of the study stems from the need to systematise existing approaches to assessing the contribution of higher education to sustainable economic development. In this article, by correlating the characteristics of the economy and public policies existing at certain stages of society development, conclusions are drawn about the factors influencing the formation of approaches to the assessment of the role of higher education. Based on the results of the analysis, the peculiarities of the development of methodological approaches in the field of research are identified, the conclusion is made about the increase in the range of indicators included in the assessments and the gradual shift of emphasis from the economic to socio-economic and humanitarian role of higher education, as well as the expansion of the interpretation of higher education and its functions.
\end{abstract}

\section{Introduction}

This study analyses the evolution of scientific approaches to analyse the role of higher education in socio-economic development.

The need to systematise scientific approaches to assessing the importance of higher education in sustainable development is due to the existence of a range of methodological approaches in the scientific literature, characterised by a lack of unity of views and a single formalised research framework in this area.

The diversity of approaches is due to a number of factors, the key ones of which are:

- high dynamics of social relations, which form the latest demands of the higher education system and require development of indicators to assess the efficiency of their satisfaction;

- balancing higher education system in state-market coordinates that require taking into account the effectiveness of regulatory impact of state and market in different periods of higher education system development;

\footnotetext{
* Corresponding author: elmo.sm@mail.ru
} 
- expanding the mission of universities, changing the focus and priorities of their activities;

- systematic reforms of Russian higher education, which cause the need to measure new states of the higher education system;

- high dynamics of transformations in the state education policy, fragmented and pinpoint targeting, causing the need for systematic monitoring of changes in the Russian higher education system.

The methodology of the study consists in the integrated application of methods: (1) causal analysis of relations between historical events and scientific approaches to the study of higher education in a specific historical period, (2) historical-genetic analysis, which allows to describe the conditions of formation of scientific approaches, (3) quantitative analysis of linguistic trends, based on syntactically annotated ngrams, (4) content analysis of scientific and normative texts.

Using the epistemological possibilities of the mentioned research methods, let us correlate the approaches existing in a particular historical period to assess the role of higher education in socio-economic development with a specific historical context, which determined the characteristic of the corresponding scientific approach.

\section{Materials and methods}

The study is based on data from a statistical analysis tool of information contained in a body of sources from Google Books [2]. It should be noted that this method has some set of assumptions and is not an accurate statistical tool. However, the correlation of the data in Figure 1 with specific historical events, as well as the content of scientific literature sources in the scope of this study allows us to draw sufficiently valid conclusions.

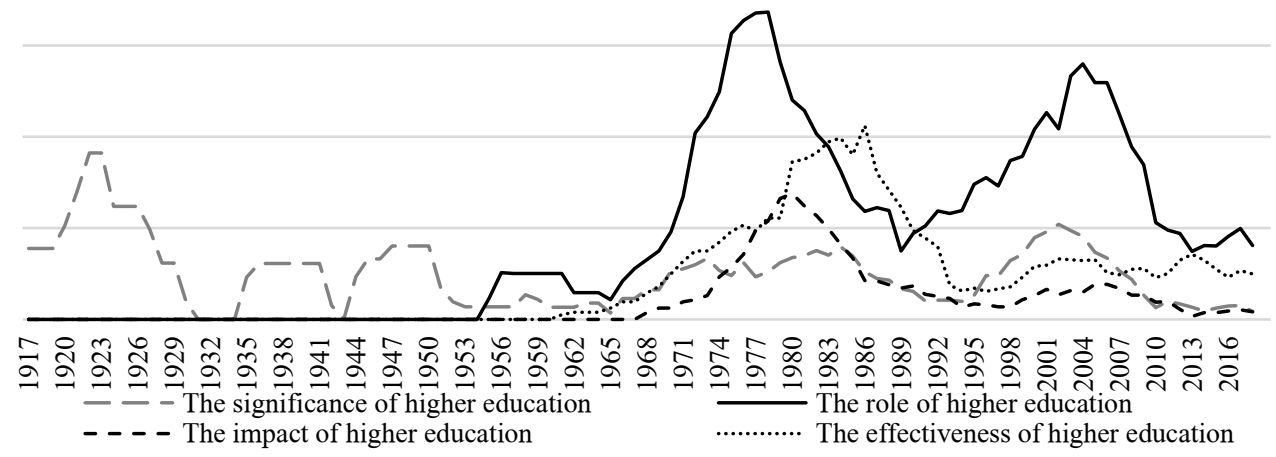

Fig. 1. Intensity of use in scientific literature of word combinations in the context of assessing the role of higher education in Russian-language sources in the period from 1970 to $2019, \%$ according to Google Ngram Viewer [1]

The analysis in this article covers the historical period from 1917 to the present. The period chosen for analysis is due to the growing interest of scholars in the study of higher education (Figure 2), which makes it possible to objectively correlate the content of scientific approaches to the analysis of the role of higher education and historical events in a particular period. 


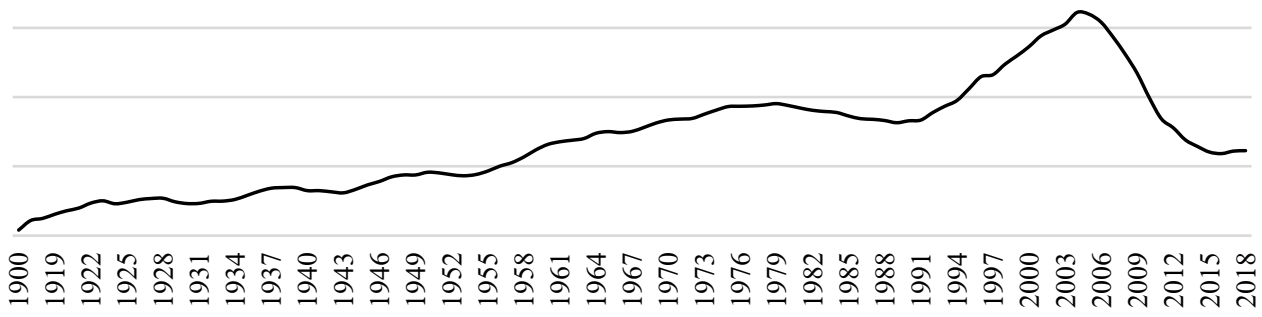

Fig. 2. Intensity of mentions of higher education in Russian-language academic sources according to Google Ngram Viewer, \%

It would be worth noting that the contexts in which the effectiveness of education in terms of its impact on society were transformed in the wake of government policy in education, but the economic architecture of social relations was a key factor in determining the vector of development in a particular period.

Anticipating the start of the analysis, we should note that in pre-revolutionary years higher education was in a unique situation of institutional diversity and pluralism of organizational forms of universities, forms of ownership, a combination of fairly formalized state regulation and the beginning of the formation of a market for higher education. Nicholas II's reforms, which preserved class differentiation, were combined with high social mobility and class diversity in private universities, which were democratic and independent of state policy. During this period, research into the purpose of higher education for society began to intensify.

The characteristics of the development of higher education in the period 1917-1930 were derived and dictated by the social and economic system of Soviet society. The tasks of higher education were subordinated to the goals set by the state and the ruling party. The key role of the SSE of that period was the formation of the class structure of society. This context set the vector for research into the effectiveness of higher education. According to B.A. PlusninKronin, the directions and content of education were determined by (1) the purposeful predetermination of the state and (2) the life, which was influencing it from all sides [2]. The role of higher education became institutionalized with the Soviet government's adoption of the Decree of August 2, 1918 «On the Admission to Higher Education Institutions in the RSFSR and the Resolution on Preferential Admission to Higher Education Institutions of the Proletariat and the Poor Peasantry». The success of ideologisation and professionalisation became the closest measure of the effectiveness of higher education up to the end of the thirties.

Two key areas of assessment of the importance of higher education can be discerned in the scholarly writings of the time:

(1) the effectiveness of higher education system in the formation of ideology (Soviet, proletarian, class). N.S. Derzhavin [3], I. Chodorovsky [4], for instance, wrote about this, and others. The analysis was conducted not only according to the criteria of the number of universities and students in them, the class structure of the students was assessed, which at the time of modernization of Russian higher education into a Soviet one was an indicator of equal accessibility and class pluralism. The number of Communist Party and Young Communist League members also demonstrated the effectiveness of ideological work. A new «political face of the student body» was being formed [5];

(2) the efficiency of provision of human resources for the Soviet national economy [3], the efficiency of «direct service of the practical and household needs of the country» [4], the coordination of higher education with the sectoral agenda, «correspondence to the structure 
of economic life» of the country [5] (criteria of the degree of professionalization of youth and the practical orientation of educational programs appeared). At the same time, the difficulty of evaluating the contribution of higher education to providing the national economy with the necessary personnel was the absence of a formalized request from the relevant sectors of the economy, as V.N. Yakovleva [5] and many others have written about it. At the same time, the implementation of staffing task was ensured through narrow professional specialization of students.

Thus, the Soviet educational policy in the 1920s-1930s was characterized by positive discrimination based on social background to ensure the formation of a social stratum - the Soviet intelligentsia loyal to the government. According to scientists, the return on higher education at that time was about 5\% [6], which is a rather low figure. However, in the conditions of directive distribution of graduates in the administrative-command economy with free higher education, the specified effect seemed reasonable and normal.

The second stage in the development of the methodology for assessing the role of higher education in the socio-economic development of Russian society, which has independent methodological approaches and indicators, can be dated from 1930-1950. This period is characterised by the established structure of Soviet society and the abandonment of the need for intensive social engineering. The focus of analysis shifted from the ideological success of Soviet higher education to assessing the quality of education. Indicators of the efficiency of the system of higher education are its ability to meet the staffing demands of the economy. Therefore, during this period, the main mission of universities was to form a professional structure of society within a utilitarian and technocratic approach to their activities. The educational organizations became subordinate to the line ministries. From 1930 to 1937 a number of normative legal acts were passed that provided, to a greater or lesser extent, material support for scientists, postgraduate students and talented students. In 1939-1940 the stimulation of scientific activity was intensively developed which marked a new stage in the development of higher education and the expansion of the mission of higher education institutions. Educational organisations received a new indicator of performance evaluation the effectiveness of scientific work, which at that time was mainly concentrated in higher education institutions.

The period from 1950 to mid-1990 is characterised by a significant increase in interest in higher education in general, and the development of methodologies to assess its role in particular (Figure 1).

Most research on the role (or contribution) of higher education has been based on work on estimating the returns to human capital. The basic premise for estimating the economic impact of education was laid down by Gary S. Becker in a series of papers in 1975. Interest in the study of higher education intensified in the context of depreciation of a significant layer of human capital, formed under the influence of Soviet ideology and the need to quickly develop qualities, knowledge, skills and abilities with the latest characteristics due to the transition to the market rails. The transformation of the Russian economic model confirmed the assumption of T. Schultz [7] about the increasing importance of higher education in the successful adaptation of actors to non-equilibrium conditions.

By the end of the period, competition between higher education institutions with the same programmes and areas of study, which had been banned back in 1919 by the Resolution of the People's Commissariat for Education «On Eliminating Parallelism in Higher Education», began to develop in Russian higher education. In connection with this there was a trend of competitiveness research both at home and abroad [8].

It should also be emphasized that the progressive increase in output from higher education in the early nineties quickly turned into an expansion of higher education, an overproduction of highly qualified staff and, consequently, a gap between the demand for highly qualified staff and the supply of highly qualified people. Thus, since the 1990s, this context has made 
it relevant to analyse not only the number of graduates and the quality of educational programmes, but also to assess supply and demand on an intensively developing higher education and labour market. By the mid-twentieth century, a persistent view emerged about the decline in the impact of higher education (Figure 3), which significantly intensified research in this area, demonstrating sometimes opposing views (for example, $\mathrm{R}$. Kapeliushnikov [9] talks about the growth of the impact of higher education, while a number of authors, on the contrary, state its decline [10]).

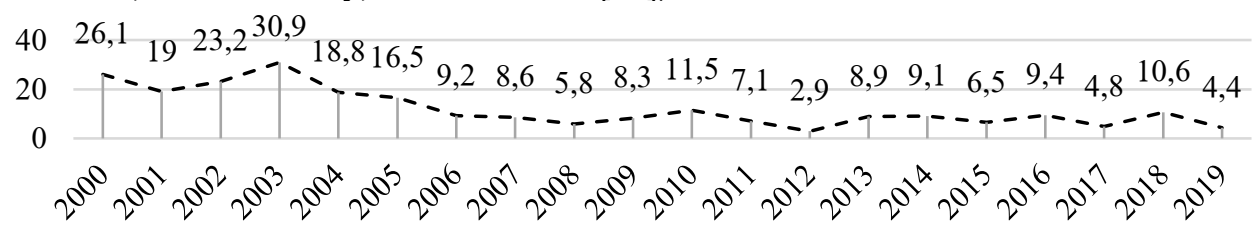

Fig. 3. Dynamics of higher education premiums, according to the Russian Economic and Health Survey of the National Research University Higher School of Economics, 2000-2019, \% [9]

The popular estimate of the rate of return on higher education is expressed in terms of the ratio of income received after the completion of an educational programme to the cost of education. In recent years, scholars have raised the issue of the correctness and objectivity of the conclusions about the decline in the role of higher education, indicating the need for a more thorough study of this issue.

The state-market coordinates of higher education have made it necessary to analyse not only the supply and demand ratio, but also the influence of other socio-economic factors [11]. In particular, the quality of entrants (initial level of knowledge and abilities), which determines the possibility of mastering an educational programme and, as a consequence, directly affects the quality of the graduate, was included in the analysis. Universal higher education, accessibility and the low cost of acquiring it devalue the value of the diploma, and consequently the impact of higher education. Academic papers have found an unprecedented expansion in the range of actors who can and do influence the fate and activities of the higher education system, from households, which have gained significant influence mechanisms by shaping demand for educational services, to employers, who are shaping demands for the professional structure of education.

While retaining the focus on the ability of SSE to meet labour market demands, indicators of education quality are also included in the analysis, which has significantly expanded J. Minser's equation that considers wages as a function of education and experience gained. It should be noted that, retrospectively, the range of indicators is widening to include an increasingly broad range of different aspects of higher education that can affect its returns. In particular, one can observe a significant attention of scholars to the analysis of the correlation between the level of education and innovative development of economies [12].

In turn, globalisation processes have put the ability of Russian higher education to compete with foreign higher education systems on the agenda. An analysis of the export of Russian higher education, the contribution of foreign students to the economy of the region of study, etc., has appeared in the works.

A new development in research in recent years is the increasing emphasis on the social [13] and humanities significance of higher education, which has significantly broadened the range of indicators analysed [14]. The departure from the Humboldtian model of universities that occurred in Russia during the revolution, and in Europe and the United States in the middle of the last century led to the loss of the role of universities as a place of preservation and reproduction of national culture, strengthening the vector of development of SSE towards the increasing commercialization of knowledge, including in studies the number of licenses and patents, contracts for research activities, incubators, technology parks, etc. 
Entropic processes in society, acceleration of information production and transmission, as well as the expansion of the number of channels of its translation, globalization of knowledge require higher education to form a professional encyclopedist, which has led to research on the ability of SSE to form the skills of continuous, timely and adequate production, search, exchange and transmission of knowledge and information. In connection with the above, in the context of superfast and poorly predictable environmental changes, competences in social interaction and the ability to learn through life [15], as well as forwardlooking thinking, have become in demand. In particular, the contribution of higher education to sustainable development is analysed [16]. This aspect involves the analysis of a set of noneconomic indicators developed by the UN, such as accessibility of higher education, the possibility of lifelong learning, the implementation of societal goals (preservation of cultural diversity, strengthening of social values, etc.), the inclusion of sustainable development principles, environmental disciplines and directions in educational programmes [17].Thus, two key tasks of the higher education system have been formed - education of the student (formation of a wide outlook, ability to produce, receive and exchange information, social interactions, mastery of various ways of communication) and professionalization (formation of a set of knowledge, skills and abilities necessary for professional activity). In the context of this area of research, the degree of involvement of higher education in solving problems important for society is assessed. The «third mission» of universities is intensively researched in terms of their ability to interact effectively with civil society institutions and to influence the sustainability of the territory [18].

\section{Results and discussion}

Thus, the field of research on the meaning (contribution or role) of higher education is always determined by the historical context of its development, which cannot be neglected for the sake of objectivity of research [19]. In the case of Russian higher education, throughout the years of its development, the state has been of key importance in defining the mission of higher education. In its turn, the vector of higher education research evolution is determined by the model of social relations and the characteristics of the national economy existing in a particular historical period (table 1). At the same time, the directions and set of analyzed indicators are unique for particular historical periods.

Table 1. Key characteristics of the higher education system and areas of research on its effectiveness in specific historical periods.

\begin{tabular}{|c|c|c|c|c|}
\hline Period & $\begin{array}{l}\text { Key objectives of } \mathrm{HE} \\
\text { (mission) }\end{array}$ & $\begin{array}{l}\text { Key features of the } \\
\text { period }\end{array}$ & $\begin{array}{l}\text { Importance of } \\
\text { the higher } \\
\text { education } \\
\text { system for } \\
\text { development }\end{array}$ & $\begin{array}{l}\text { Directions for } \\
\text { assessing } \\
\text { effectiveness } \\
\text { (impact, } \\
\text { contribution) of the } \\
\text { HE }\end{array}$ \\
\hline $\begin{array}{l}1917- \\
1930\end{array}$ & $\begin{array}{l}\text { (1) transmission of the } \\
\text { ideology } \\
\text { (2) knowledge } \\
\text { transfers }\end{array}$ & $\begin{array}{l}\text { (1) Directive } \\
\text { placement } \\
\text { graduates in an } \\
\text { administrative- } \\
\text { command economy } \\
\text { (2) free higher } \\
\text { education }\end{array}$ & $\begin{array}{l}\text { Shaping the } \\
\text { class structure } \\
\text { of society }\end{array}$ & $\begin{array}{l}\text { (1) the effectiveness } \\
\text { of the higher } \\
\text { education system in } \\
\text { shaping ideology } \\
\text { (2) the effectiveness } \\
\text { of staffing the Soviet } \\
\text { national economy }\end{array}$ \\
\hline
\end{tabular}


Table 1. Continued

\begin{tabular}{|c|c|c|c|c|}
\hline $\begin{array}{l}1930- \\
1980\end{array}$ & $\begin{array}{l}\text { (1) professionalisation } \\
\text { of the population } \\
\text { (2) knowledge } \\
\text { transmission } \\
\text { (3) applied scientific } \\
\text { research }\end{array}$ & $\begin{array}{l}\text { (1) universal } \\
\text { acceptance of Soviet } \\
\text { ideology } \\
\text { (2) free higher } \\
\text { education } \\
\text { (3) a utilitarian and } \\
\text { technocratic } \\
\text { approach } \\
\text { universities } \\
\end{array}$ & $\begin{array}{l}\text { Shaping the } \\
\text { professional } \\
\text { structure of } \\
\text { society }\end{array}$ & $\begin{array}{l}\text { (1) the efficiency of } \\
\text { staffing the Soviet } \\
\text { national economy } \\
\text { (3) the efficiency of } \\
\text { universities' } \\
\text { scientific activities } \\
\text { for the national } \\
\text { economy }\end{array}$ \\
\hline $\begin{array}{l}\text { Mid- } \\
\text { nineti } \\
\text { es- } \\
2000\end{array}$ & $\begin{array}{l}\text { (1) knowledge } \\
\text { transmission } \\
\text { (2) professionalisation } \\
\text { (3) applied and } \\
\text { fundamental research } \\
\text { (4) development of } \\
\text { mechanisms to adapt to } \\
\text { changing conditions }\end{array}$ & $\begin{array}{l}\text { ((1) liberalisation } \\
\text { (2) competition } \\
\text { (3) expansion of } \\
\text { higher education } \\
\text { (4) devaluation of } \\
\text { human capital } \\
\text { formed under the } \\
\text { influence of Soviet } \\
\text { ideology }\end{array}$ & $\begin{array}{l}\text { Successful } \\
\text { adaptation of } \\
\text { actors to non- } \\
\text { equilibrium } \\
\text { conditions }\end{array}$ & $\begin{array}{l}\text { (1) economic } \\
\text { efficiency of the } \\
\text { economic activities } \\
\text { of higher education } \\
\text { institutions } \\
\text { (2) } \\
\text { commercialisation of } \\
\text { knowledge } \\
\text { (3) rates of return on } \\
\text { higher education }\end{array}$ \\
\hline $\begin{array}{l}2000- \\
\text { presen } \\
\mathrm{t}\end{array}$ & $\begin{array}{l}\text { ((1) Knowledge } \\
\text { transmission } \\
\text { (education) } \\
(2) \text { knowledge } \\
\text { production (applied } \\
\text { and basic scientific } \\
\text { research) } \\
(3) \text { commercialization } \\
\text { of knowledge produced } \\
\text { (4) involvement in } \\
\text { solving problems of } \\
\text { importance to society }\end{array}$ & $\begin{array}{l}\text { (1) globalisation } \\
\text { (2) digitalisation } \\
\text { (3) lifelong learning } \\
\text { (4) communications }\end{array}$ & $\begin{array}{l}\text { A tool for } \\
\text { economic } \\
\text { growth in the } \\
\text { context of the } \\
\text { knowledge } \\
\text { economy }\end{array}$ & $\begin{array}{l}\text { (1) } \\
\text { commercialisation of } \\
\text { knowledge } \\
\text { (2) digitalisation } \\
\text { (3) contribution of } \\
\text { higher education to } \\
\text { sustainable } \\
\text { economic } \\
\text { development } \\
\text { (4) impact on the } \\
\text { sustainability of the } \\
\text { area }\end{array}$ \\
\hline
\end{tabular}

\section{Conclusion}

In this article, by correlating the characteristics of the economy and public policy existing at certain stages of society development, conclusions are drawn about the factors influencing the formation of approaches to the assessment of the role of higher education.

The analysis of the evolution of scientific approaches to the analysis of the contribution of higher education to socio-economic development of society has allowed us to identify a number of trends that characterise the development of research in this area.

Firstly, science is moving towards including more and more indicators that form the most complete picture of the importance of higher education;

Secondly, more and more researchers are shifting their focus from the economic to the socio-economic and humanities role of higher education;

Thirdly, the empirical basis of research is not sufficient and often the results of analysis depend on the correct inclusion or non-inclusion of particular indicators in the analysis, with or without taking into account the historical context;

Fourthly, the retrospective view of higher education has evolved from a simple, linear, closed, highly centralised and state-controlled system to an autonomous, complex, highly differentiated, institutionally diverse, heterogeneously structured, open and non-linear system; 
Fifthly, the expansion of scientific approaches to the analysis of the role of the higher education system is largely due to the diffusion of stakeholder theory into academic research, which allows the function of higher education to expand from meeting the interests of one actor - the state - to a wide range of stakeholders (students, households, society), which has significantly affected the vector of the role of the higher education system.

Sixthly, the institutional isomorphism [20] present in academic research has also broadened the interpretation of the role of higher education in the context of the need to adapt and interact with multiple agents of influence.

\section{References}

1. Google Ngram Viewer - a tool for statistical analysis of information contained in an array of sources from Google Books, https://books.google.com/

2. B.A. Plyusnin-Kronin, New stage: The new system of public education in the RSFSR and new programmes of the State Academic Council, 84 (Worker of Education, 1925) http://biografia.ru

3. N.S. Derzhavin, Higher School and Revolution, 60 http://elib.shpl.ru/

4. I. Chodorovsky, At the Front of Enlightenment: Articles and Speeches, 176 (Leningrad: State Publishing House, 1926) http://biografia.ru

5. V.N. Yakovleva, General state of vocational education in the RSFSR, 19 (State Publishing House, 1922), https://ruthenia.ru/

6. P. Graeser, Kyklos, 41, 75 (1988)

7. T. Schultz, Journal of Economic Literature, 13, 827 (1975)

8. NL. Sum, B. Jessop, J Knowl Econ, 4, 24 (2013)

9. R.I. Kapelyushnikov, Education output in Russia: no lower, 52 (Moscow : Higher School of Economics Publisher, 2021)

10. N.E. Tikhonova, A.V. Karavay, Mir Rossii, 26(3), 6 (2017)

11. M. Shrivastava, S. Shrivastava, High Educ, 67, 809 (2014)

12. P. Aghion, Economic policy, 25(61), 7 (2010)

13. R. Barnett, Educ Philos Theory, 49(1), 78 (2017)

14. K. H., Brown, M. T. Heaney, Research on higher education, 38, 229 (1997)

15. L. Anthonysamy, A. C. Koo, S. H. Hew, Educ Inf Technol, 25, 2393 (2020)

16. K. Shephard, Higher Education for Sustainability. Education for Sustainability (2020)

17. UNESCO Roadmap for Implementing the Global Action Programme on Education for Sustainable Development, https://unesdoc.unesco.org

18. J. Alves, L. Carvalho, R. Carvalho, Tert Educ Manag, 21, 81 (2015)

19. T. Kromydas, Palgrave Commun, 3, 1 (2017)

20. Y.I. Kuzminov, D.S. Semenov, I.D. Frumin, Education Issues, 4, 8 (2013) 